\title{
Effect of whole linseed (Linum usitatissimum) in the diet of finishing pigs on growth performance and on the quality and fatty acid composition of various tissues
}

\author{
K. R. Matthews ${ }^{1 *}$, D. B. Homer ${ }^{1}$, F. Thies ${ }^{2}$ and P. C. Calder ${ }^{2}$ \\ ${ }^{1}$ Meat and Livestock Commission, PO Box 44, Winterhill House, Snowdon Drive, Milton Keynes MK6 1AX, UK \\ ${ }^{2}$ Institute of Human Nutrition, University of Southampton, Bassett Crescent East, Southampton SO16 7PX, UK
}

(Received 3 March 1999 - Revised 18 November 1999 - Accepted 18 November 1999)

\begin{abstract}
Pigs ( $n$ 144, $30 \mathrm{~kg}$ liveweight) were allocated to one of three diets differing in the level of whole linseed (Linum usitatissimum, also known as flaxseed). The diets contained 0,50 and $100 \mathrm{~g} / \mathrm{kg}$ for diets L0, L50 and L100 respectively, while containing a constant oil content $(60 \mathrm{~g} / \mathrm{kg})$. Pigs were slaughtered at a liveweight of $77-87 \mathrm{~kg}$. With the exception of a slight difference in feed intake, there was no effect of diet on production characteristics or carcass traits. Levels of $\alpha$-linolenic acid were increased in all tissues studied as the amount of linseed in the diet increased. In the plasma, $m$. longissimus thoracis, liver and kidney eicosapentaenoic acid concentration increased markedly. Docosapentaenoic acid concentration increased in the muscle, liver and kidney, whereas in the plasma higher levels of docosahexaenoic acid were observed. None of the longerchain fatty acids (C20 or longer) were detected in the subcutaneous fat. The changes in fatty acid composition resulted in marked changes to the $n-6: n-3$ and arachidonic : eicosapentaenoic acid ratios. Feeding whole linseed had no negative effect on the oxidative stability of the meat. Sensory panel results showed no significant differences by diet except for a reduction in abnormal odour (odour perceived by panellists to be abnormal in pigmeat) in the L50 diet and a reduction in the skatole odour (odour of 3-methylindole) in the pigs fed on diet L100. It is concluded that increasing the linseed content of pig diets up to $100 \mathrm{~g} / \mathrm{kg}$ has no adverse effect on the carcass or meat quality whilst enhancing the levels of $n-3$ fatty acids which have a potentially positive health effect in man.
\end{abstract}

\section{n-3 Fatty acids: Linseed: Pigs}

The long-chain $n-3$ polyunsaturated fatty acids (PUFA) eicosapentaenoic acid $(20: 5 n-3)$ and docosahexaenoic acid $(22: 6 n-3)$, which are found in significant proportions in fish oil, have a wide range of biological effects which together are believed to confer benefits to human health (British Nutrition Foundation, 1992). As a result of these benefits, it is now widely recommended that long-chain $n$ - 3 PUFA consumption should be increased in the human diet. This could be brought about by supplementation of the diet with encapsulated fish-oil, by increasing the consumption of fish and fish products rich in long-chain $n-3$ PUFA, or by enriching traditionally consumed foods such as eggs and meat with long-chain $n$-3 PUFA. Pigs, whilst not recognized as having a nutritional requirement for $n-3$ fatty acids, are possible vehicles for supplying them to the human diet. Previous studies have shown that feeding pigs on a diet containing fish oil leads to significant enrichment of some tissues with eicosapentaenoic and docosahexaenoic acids without detrimentally affecting meat quality (Irie \& Sakimoto, 1992; Leskanich et al. 1997), although the carcass fat was softer. There is however, increasing concern regarding the sustainability of the use of fish products in animal feeds, and whilst this is a contentious issue, it has been considered important to examine possible alternative sources of long-chain $n$-3 PUFA (Givens, 1997). Furthermore, fish oil is a costly source of dietary energy relative to other feed ingredients.

An alternative means of increasing the long-chain $n-3$ PUFA content of pig tissues would be to include $\alpha$-linolenic acid $(18: 3 n-3)$, the precursor to eicosapentaenoic and docosahexaenoic acids, in the feed. A potential commercial source of 18:3n-3 for pigs is whole linseed (flax, Linum usitatissimum) which contains about one-third oil, of which just over $50 \%$ is $18: 3 n-3$. Feeding linseed has advantages over use of the oil in terms of practicality and due to its natural antioxidant content (Cunnane et al. 1990). In North 
America, where edible linseed has become known as flaxseed, pigs have been fed on linseed with no detrimental effects on production or carcass traits (Cunnane et al. 1990; Romans et al. 1995a,b).

Whilst there is clearly evidence that the $n-3$ content of pork products can be enhanced by use of linseed in the diet, there is no published work on the effect of feeding linseed under British conditions on pig-meat fatty acid composition or quality. In comparison with American genotypes, British pigs are leaner and leaner pigs have been shown to more readily exhibit quality problems such as soft fat or abnormal flavour (Wood, 1984).

\section{Materials and methods}

\section{Animals and diets}

Pigs ( $n$ 144) were taken from three commercial genotypes selected to represent a cross-section of finishing pigs in Great Britain, as groups of three litter mates of a single sex. From approximately $30 \mathrm{~kg}$ liveweight the three pigs from each litter were allocated to receive one of three diets differing in the level of whole linseed that they contained: 0,50 and $100 \mathrm{~g} / \mathrm{kg}$ (diets L0, L50 and L100 respectively) as shown in Table 1. Diets were formulated to be equal in oil content (approximately $60 \mathrm{~g} / \mathrm{kg}$, using full-fat soyabean and tallow-soyabean oil $(80: 20, \mathrm{w} / \mathrm{w})$ to replace the oil from linseed) so that any effects could be attributed to the type of oil in the diet rather than its level. Oil contents as analysed were 64, 67 and $74 \mathrm{~g} / \mathrm{kg}$ for diets L0, L50 and L100 respectively, demonstrating some difficulty in formulating to a constant oil content. The diets were free from fish meal and fish oil and were formulated to meet the requirements of the Meat and Livestock Commission's Blueprint for Quality British Pork (Meat and Livestock Commission, 1996) including the use of vitamin $\mathrm{E}$ at $100 \mathrm{IU} / \mathrm{kg}$ feed. The diet formulations resulted in differing fatty acid compositions, as shown in Table 2. The main effects of increasing the level of linseed in the diet were a reduction in the levels of the saturated fatty acids palmitic acid (16:0) and stearic acid $(18: 0)$ and the unsaturated fatty acids oleic acid $(18: 1)$ and linoleic $(18: 2 n-6)$ together with an increase in the level of $\alpha$-linolenic acid (18:3n-3).

Pigs were fed ad libitum in single sex pairs. The weight of

Table 1. Composition of the experimental diets ( $\mathrm{g} / \mathrm{kg}$ wet wt.)*

\begin{tabular}{|c|c|c|c|}
\hline \multirow[b]{2}{*}{ Ingredients } & \multicolumn{3}{|c|}{ Diet } \\
\hline & LO & L50 & L100 \\
\hline Barley & 120 & 100 & 105 \\
\hline Wheat & 368 & 360 & 383 \\
\hline Wheatfeed & 200 & 200 & 175 \\
\hline Whole linseed & 0 & 50 & 100 \\
\hline High-protein soyabean & 233 & 250 & 213 \\
\hline Full-fat soyabean & 30 & 0 & 0 \\
\hline Fat blend $\dagger$ & 25 & 16 & 0 \\
\hline Vitamins and minerals $\ddagger$ & 26 & 26 & 26 \\
\hline
\end{tabular}

Table 2. Fatty acid composition of the treatment diets $(\mathrm{g} / 100 \mathrm{~g}$ total fatty acids)

(Mean values of three determinations)

\begin{tabular}{lrrr}
\hline & \multicolumn{3}{c}{ Linseed content of diet $(\mathrm{g} / \mathrm{kg})$} \\
\cline { 2 - 4 } Fatty acid & \multicolumn{1}{c}{0} & \multicolumn{1}{c}{50} & 100 \\
\hline $14: 0$ & 0.80 & 0.66 & 0.19 \\
$16: 0$ & 20.13 & 15.03 & 11.61 \\
$16: 1 n-7$ & 0.72 & 0.45 & 0.20 \\
$17: 0$ & 0.24 & 0.25 & 0.11 \\
$18: 0$ & 7.37 & 6.41 & 4.30 \\
$18: 1 n-9$ & 29.62 & 24.37 & 20.84 \\
$18: 2 n-6$ & 35.51 & 30.63 & 28.46 \\
$18: 3 n-3$ & 3.30 & 20.54 & 32.78 \\
$20: 0$ & 0.36 & 0.27 & 0.23 \\
\hline
\end{tabular}

each pig was recorded at the beginning and end of the trial feeding period. Feed intake was measured for each pair of pigs by weighing all feed offered and weighing back any removed from the trough or remaining at the end of test. Pigs were slaughtered at a commercial abattoir when their liveweight was between 77 and $87 \mathrm{~kg}$ (to approximate an average carcass weight of $66 \mathrm{~kg}$ ) following about $65 \mathrm{~d}$ on the test diets. Carcass weight was recorded.

\section{Carcass evaluation}

Backfat thickness was measured at a point $60 \mathrm{~mm}$ from the midline of the carcass at the head of the last rib $\left(\mathrm{P}_{2}\right.$ fat depth, $\mathrm{P}_{2}$ ) and at a point $60 \mathrm{~mm}$ from the midline between the third and fourth last rib (rib fat, RF) using a Fat-O-Meater ${ }^{\mathrm{TM}}$ probe (SFK Technology, Herlev, Denmark). The Fat-OMeater ${ }^{\mathrm{TM}}$ measures lean and fat depths automatically by insertion of a probe which distinguishes between the fat and the lean by the measurement of reflectance. Rib muscle (muscle depth at the same position as rib fat, RM) was also recorded using the Fat-O-Meater ${ }^{\mathrm{TM}}$. From these measurements, the percentage lean in the carcass was estimated using the European Union approved equation for use of the Fat-O-Meater ${ }^{\mathrm{TM}}$ in Great Britain (lean meat $(\%)=59.0-$ $\left.0 \cdot 58 \mathrm{P}_{2}-0 \cdot 32 \mathrm{RF}+0 \cdot 18 \mathrm{RM}\right)$ (EU Commission Decision $88 / 234 /$ EEC). The $\mathrm{P}_{2}$ fat depth and muscle depth at the same position were also measured using callipers on the cold carcass. The firmness of fat was assessed subjectively by a trained assessor and objectively using a hand-held Penetrometer (H \& B Sensors, Bognor Regis, UK) (a spring loaded plunger which is used to assess firmness by the extent to which it will depress the fat surface, first reported by Dransfield \& Kempster, 1988) on the split surface at the last rib and at a point posterior to the gluteus muscle. Drip loss was determined as the percentage of muscle weight lost from a $20 \mathrm{~mm}$ thick chop suspended in a bag for $48 \mathrm{~h}$. Muscle colour was evaluated subjectively on a scale $1-6$ by comparison with a Japanese pork colour scale (The Japan Ham and Sausage Processors Cooperative Association, Tokyo, Japan).

\section{Chemical analysis}

Samples of plasma, liver, kidney, $m$. longissimus thoracis, and inner and outer layers of subcutaneous fat were frozen 
before analysis of samples from a subset of pigs ( $n 6$ per treatment) for determination of fatty acid composition. Lipid extraction was carried out according to Bligh \& Dyer (1959). Before extraction, tissues were homogenized in methanol, and then chloroform and water were added to give a chloroform-methanol-water mixture $(1: 1: 0 \cdot 8$, by vol.). Fatty acid methyl esters were prepared by heating with boron trifluoride $(140 \mathrm{~g} / \mathrm{l})$ at $80^{\circ}$ for $30 \mathrm{~min}$. Fatty acid methyl esters were isolated by solvent extraction, dried, and separated by GC in a Hewlett-Packard 6890 gas chromatograph (Hewlett-Packard, Avondale, PA, USA) fitted with a $25 \mathrm{~m} \times 0.32 \mathrm{~mm}$ BPX70 capillary column (SGE Ltd, Milton Keynes, Bucks, UK), film thickness $0.25 \mu \mathrm{m}$. He at $2.0 \mathrm{ml} / \mathrm{min}$ was used as the carrier gas and the split/splitless injector was used with a split:splitless ratio of $10: 1$. Injector and detector temperatures were $270^{\circ}$ and $270^{\circ}$ respectively. The column oven temperature was maintained at $170^{\circ}$ for 12 min after sample injection and was programmed to then increase from $170^{\circ}$ to $200^{\circ}$ at $5 \% \mathrm{~min}$ before being maintained at $200^{\circ}$ for $15 \mathrm{~min}$. The separation was recorded with HP GC Chem Station software (HewlettPackard). Fatty acid methyl esters were identified by comparison with standards run previously.

To assess the impact of the treatment diets on the development of lipid oxidation products, the malondialdehyde concentrations of loin steaks (prepared from the $m$. longissimus thoracis with associated subcutaneous fat) were estimated by measurement of thiobarbituric acid reactive substances (TBARS; Placer et al. 1966). This was carried out in two steaks per animal in the subset of pigs $(n 18)$. One of these was frozen the day after slaughter and the other after storage at $1^{\circ}$ in a vacuum package as part of the primal loin for $14 \mathrm{~d}$ before freezing to give an indication of rancidity development on storage. For measurement of TBARS, samples were homogenized in $0.2 \mathrm{M}$-Tris/ $0 \cdot 16 \mathrm{M}$ $\mathrm{KCl}, \mathrm{pH} 7.4$ buffer (ratio of tissue to buffer $1: 10$ ) and the homogenate incubated at $37^{\circ}$ for $1 \mathrm{~h}$. The homogenate was centrifuged and $0.5 \mathrm{ml}$ of the supernatant fraction taken and mixed with $1 \mathrm{ml} 10.5 \mathrm{mM}$-thiobarbituric acid in $0.11 \mathrm{M}$ phosphoric acid. The mixture was boiled for $1 \mathrm{~h}$ and then cooled. Then $0.5 \mathrm{ml}$ was transferred to tubes containing $0.5 \mathrm{ml} 0.1 \mathrm{M}-\mathrm{NaOH}$ in methanol $(900 \mathrm{ml} / \mathrm{l})$. The absorbance was then read at $532 \mathrm{~nm}$ and the concentration of malondialdehyde calculated by reference to a standard curve constructed using different concentrations of 1,1,3,3-tetraethoxypropane which was determined at the same time as the samples were analysed.

\section{Sensory panel evaluation}

Two boneless rindless $20 \mathrm{~mm}$ loin steaks were taken from the $m$. longissimus lumborum, with associated fat, for sensory panel evaluation. Assessment of grilled steaks was undertaken by trained sensory panellists according to the procedures described by Vipond et al. (1995) and who were trained according to British Standard 7667 (British Standards Institute, 1994). Lean and fat components of the steaks were assessed by mouth and panellists assessed odour characteristics on a sample of the cooked fat. Thirteen attributes, including overall acceptability were scored on a 24 point pseudo line scale. Each session consisted of six samples, one of each dietary treatment and sex combination.

\section{Statistical analysis}

Data analysis was carried out by least squares. The basic model included terms for diet, sex and genotype with terms for slaughter date or sensory panel session where appropriate. Least square means for growth traits were regressed to a constant start and end weight, all other means were regressed to a constant carcass weight. Interactions were investigated and included in the model if they reached significance at the $5 \%$ level. For chemical analysis a simple one-way ANOVA was used, pooling the error across treatments due to the size of the data set.

\section{Results \\ Production and carcass attributes}

Although pigs fed on diet L50 ate more than pigs fed on diet L0 there were no significant differences in the daily liveweight gain or feed conversion ratio of pigs fed on the different diets (Table 3).

No significant differences in carcass quality (fat and lean content and the carcass weight as a percentage of the liveweight) were found, although there were significant interactions between genotype and diet for fat depths and the resulting predicted lean (results not shown). The data suggested that pigs of one genotype fed on diet L0 were fatter than pigs from other genotypes fed on the same diet. Differences between genotypes for pigs fed diets L50 and L100 were not significant. Similarly, there were no significant differences between pigs fed on different diets for their fat firmness, colour or drip loss.

Table 3. Least square means for growth traits in pigs fed on a diet containing whole linseed (Mean values for forty-eight pigs per group with their pooled standard error)

\begin{tabular}{lcccccc}
\hline & \multicolumn{3}{c}{ Diet† } & & \multicolumn{2}{c}{ ANOVA } \\
\cline { 2 - 3 } Growth trait & LO & L50 & L100 & & $P$ & Pooled SE \\
\hline Feed intake (kg/pig per d) & 2.00 & 2.14 & 2.10 & & $*$ & 0.05 \\
Growth rate (g/d) & 854 & 832 & 860 & & NS & 12 \\
Days on test & 65.7 & 66.0 & 63.8 & & NS & 1.33 \\
FCR (kg feed/kg liveweight gain) & 2.40 & 2.58 & 2.44 & & NS & 0.065 \\
\hline
\end{tabular}

FCR, feed conversion ratio.

${ }^{*} P<0.05$.

†For details of composition of diets see Tables 1 and 2. 
Table 4. Fatty acid profiles ( $\mathrm{g} / 100 \mathrm{~g}$ total fatty acids) in plasma of pigs fed on a diet containing whole linseed

(Mean values for forty-eight pigs per group with their pooled standard error)

\begin{tabular}{|c|c|c|c|c|c|}
\hline \multirow[b]{2}{*}{ Fatty acid } & \multicolumn{3}{|c|}{ Diet† } & \multicolumn{2}{|c|}{ ANOVA } \\
\hline & LO & L50 & L100 & $P$ & Pooled SE \\
\hline $16: 0$ & $18 \cdot 4$ & $17 \cdot 1$ & 15.9 & * & 0.57 \\
\hline $18: 0$ & $12 \cdot 6$ & $12 \cdot 3$ & $13 \cdot 1$ & NS & 0.49 \\
\hline $18: 1 n-9$ & $22 \cdot 1$ & $20 \cdot 0$ & $19 \cdot 3$ & * & 0.74 \\
\hline $18: 2 n-6$ & $34 \cdot 1$ & $33 \cdot 3$ & 31.4 & NS & $1 \cdot 13$ \\
\hline $18: 3 n-3$ & 1.7 & $6 \cdot 2$ & 7.9 & * & 1.29 \\
\hline $20: 4 n-6$ & $6 \cdot 8$ & 4.8 & 4.5 & * & 0.54 \\
\hline $20: 5 n-3$ & 0.7 & 1.7 & 2.5 & * & 0.45 \\
\hline $22: 5 n-3$ & 1.5 & 1.5 & 1.5 & NS & 0.13 \\
\hline $22: 6 n-3$ & 0.8 & 1.3 & $1 \cdot 7$ & * & 0.22 \\
\hline$P: S$ & 1.4 & 1.5 & 1.4 & NS & 0.05 \\
\hline$n-6: n-3$ & 8.9 & 3.9 & 2.9 & $\star \star$ & 1.00 \\
\hline $20: 4 n-6: 20: 5 n-3$ & $12 \cdot 4$ & 3.6 & $3 \cdot 1$ & ** & 1.75 \\
\hline
\end{tabular}

$\mathrm{P}$, polyunsaturated fatty acids; $\mathrm{S}$, saturated fatty acids. ${ }^{\star} P<0.05,{ }^{\star \star} P<0.01$.

†For details of composition of diets see Tables 1 and 2.

\section{Chemical analysis}

Fatty acid profiles for plasma, muscle, liver, kidney, inner backfat and outer backfat are shown in Tables 4-9 respectively. In summary, 18:3n-3 was increased in all tissues studied as the amount of linseed in the diet increased, with the exception of the subcutaneous fat. In the subcutaneous fat $18: 3 n-3$ did not differ between L50 and L100 although both were at least double the control diet. Some tissues showed a clear increase in the levels of longer-chain $n-3$ fatty acids. In the plasma, muscle, liver and kidney $20: 5 n-3$ increased markedly. The level of docosapentaenoic acid (22:5n-3) increased in the muscle, liver and kidney, whereas in the plasma higher levels of $22: 6 n$-3 were observed. The increase in $n-3$ fatty acids was accompanied by corresponding decreases in other fatty acids. The level of 16:0 was reduced in all tissues except the kidney and the

Table 5. Fatty acid profiles ( $\mathrm{g} / 100 \mathrm{~g}$ total fatty acids) in muscle of pigs fed on a diet containing whole linseed

(Mean values for forty-eight pigs per group with their pooled standard error)

\begin{tabular}{|c|c|c|c|c|c|}
\hline \multirow[b]{2}{*}{ Fatty acid } & \multicolumn{3}{|c|}{ Diet† } & \multicolumn{2}{|c|}{ ANOVA } \\
\hline & LO & L50 & L100 & $P$ & Pooled SE \\
\hline $16: 0$ & $21 \cdot 6$ & 18.5 & $20 \cdot 6$ & * & 0.75 \\
\hline $18: 0$ & $10 \cdot 8$ & $10 \cdot 3$ & $11 \cdot 1$ & NS & 0.44 \\
\hline $18: 1 n-9$ & $29 \cdot 3$ & $29 \cdot 1$ & $26 \cdot 9$ & NS & 1.95 \\
\hline $18: 2 n-6$ & $22 \cdot 1$ & $22 \cdot 6$ & $23 \cdot 2$ & NS & $1 \cdot 70$ \\
\hline $18: 3 n-3$ & $1 \cdot 1$ & 3.3 & 3.9 & * & 0.64 \\
\hline $20: 4 n-6$ & 4.7 & 3.5 & $3 \cdot 2$ & NS & 0.48 \\
\hline $20: 5 n-3$ & 0.6 & 1.8 & 1.9 & $\star \star \star$ & 0.22 \\
\hline $22: 5 n-3$ & $1 \cdot 3$ & $2 \cdot 2$ & $2 \cdot 0$ & * & $0 \cdot 20$ \\
\hline $22: 6 n-3$ & 0.8 & 0.8 & 0.7 & NS & $0 \cdot 10$ \\
\hline$P: S$ & 0.9 & 1.0 & 0.9 & NS & $0 \cdot 12$ \\
\hline$n-6: n-3$ & $7 \cdot 2$ & 3.5 & 3.9 & $\star *$ & 0.60 \\
\hline $20: 4 n-6: 20: 5 n-3$ & $7 \cdot 7$ & $2 \cdot 2$ & 4.3 & $\star \star$ & 0.92 \\
\hline
\end{tabular}

$\mathrm{P}$, polyunsaturated fatty acids; $\mathrm{S}$, saturated fatty acids.

${ }^{*} P<0.05,{ }^{* *} P<0.01$

†For details of composition of diets see Tables 1 and 2.
Table 6. Fatty acid profile ( $\mathrm{g} / 100 \mathrm{~g}$ total fatty acids) in liver of pigs fed on a diet containing whole linseed

(Mean values for forty-eight pigs per group with their pooled standard error)

\begin{tabular}{|c|c|c|c|c|c|}
\hline \multirow[b]{2}{*}{ Fatty acid } & \multicolumn{3}{|c|}{ Diet† } & \multicolumn{2}{|c|}{ ANOVA } \\
\hline & LO & L50 & L100 & $P$ & Pooled SE \\
\hline $16: 0$ & 13.9 & $12 \cdot 1$ & 9.9 & * & 0.83 \\
\hline $18: 0$ & $23 \cdot 1$ & $24 \cdot 6$ & $23 \cdot 1$ & NS & 0.53 \\
\hline $18: 1 n-9$ & $12 \cdot 9$ & 12.5 & $11 \cdot 6$ & NS & 0.45 \\
\hline $18: 2 n-6$ & $18 \cdot 1$ & $19 \cdot 7$ & $18 \cdot 3$ & NS & 0.64 \\
\hline $18: 3 n-3$ & 0.8 & $2 \cdot 8$ & 4.4 & $\star \star \star \star ~$ & 0.55 \\
\hline $20: 4 n-6$ & $17 \cdot 2$ & 12.5 & 12.5 & * & 1.19 \\
\hline $20: 5 n-3$ & 1.2 & 4.0 & 5.9 & ** & 0.79 \\
\hline $22: 5 n-3$ & 3.8 & 3.7 & $6 \cdot 2$ & * & 0.69 \\
\hline $22: 6 n-3$ & $2 \cdot 2$ & 1.7 & $2 \cdot 2$ & NS & 0.22 \\
\hline$P: S$ & 1.2 & 1.2 & 1.4 & NS & 0.09 \\
\hline$n-6: n-3$ & 4.7 & 2.9 & 1.8 & $\star \star \star *$ & 0.39 \\
\hline $20: 4 n-6: 20: 5 n-3$ & $16 \cdot 1$ & $6 \cdot 5$ & $2 \cdot 6$ & $* *$ & $2 \cdot 64$ \\
\hline
\end{tabular}

$\mathrm{P}$, polyunsaturated fatty acids; $\mathrm{S}$, saturated fatty acids. ${ }^{*} P<0.05,{ }^{\star *} P<0.01,{ }^{\star \star *} P<0.001$

†For details of composition of diets see Tables 1 and 2.

Table 7. Fatty acid profile ( $\mathrm{g} / 100 \mathrm{~g}$ total fatty acids) in kidney of pigs fed on a diet containing whole linseed

(Mean values for forty-eight pigs per group with their pooled standard error)

\begin{tabular}{|c|c|c|c|c|c|}
\hline \multirow[b]{2}{*}{ Fatty acid } & \multicolumn{3}{|c|}{ Diet† } & \multicolumn{2}{|c|}{ ANOVA } \\
\hline & LO & L50 & L100 & $P$ & Pooled SE \\
\hline $16: 0$ & $18 \cdot 4$ & $17 \cdot 9$ & $17 \cdot 8$ & NS & 0.53 \\
\hline $18: 0$ & 13.9 & 14.5 & $14 \cdot 8$ & NS & 0.44 \\
\hline $18: 1 n-9$ & 13.5 & $12 \cdot 1$ & $13 \cdot 3$ & NS & 0.42 \\
\hline $18: 2 n-6$ & $18 \cdot 9$ & $20 \cdot 7$ & $20 \cdot 0$ & * & 0.38 \\
\hline $18: 3 n-3$ & 0.9 & $2 \cdot 8$ & $4 \cdot 7$ & $\star \star \star *$ & 0.39 \\
\hline $20: 4 n-6$ & $17 \cdot 3$ & $13 \cdot 4$ & $11 \cdot 3$ & $* \star *$ & 0.59 \\
\hline $20: 5 n-3$ & $1 \cdot 7$ & $4 \cdot 2$ & $4 \cdot 4$ & $* \star *$ & 0.31 \\
\hline $22: 5 n-3$ & $2 \cdot 3$ & $2 \cdot 7$ & $3 \cdot 1$ & * & $0 \cdot 18$ \\
\hline $22: 6 n-3$ & 1.9 & 1.4 & $1 \cdot 3$ & NS & 0.23 \\
\hline$P: S$ & $1 \cdot 4$ & $1 \cdot 3$ & $1 \cdot 3$ & NS & 0.05 \\
\hline$n-6: n-3$ & $5 \cdot 6$ & $3 \cdot 1$ & $2 \cdot 5$ & $\star * *$ & 0.25 \\
\hline $20: 4 n-6: 20: 5 n-3$ & $10 \cdot 7$ & $3 \cdot 3$ & $2 \cdot 7$ & $\star \star \star *$ & 0.70 \\
\hline
\end{tabular}

$P$, polyunsaturated fatty acids; $S$, saturated fatty acids. ${ }^{*} P<0.05,{ }^{* * *} P<0.001$

†For details of composition of diets see Tables 1 and 2 .

Table 8. Fatty acid profile ( $\mathrm{g} / 100 \mathrm{~g}$ total fatty acids) in inner backfat of pigs fed on a diet containing whole linseed

(Mean values for forty-eight pigs per group with their pooled standard error)

\begin{tabular}{lrrrrrr}
\hline & \multicolumn{3}{c}{ Diet† } & & \multicolumn{2}{c}{ ANOVA } \\
\cline { 2 - 3 } \cline { 6 - 7 } Fatty acid & LO & L50 & L100 & & $P$ & Pooled SE \\
\hline $16: 0$ & 21.0 & 19.1 & 20.9 & & * \\
$18: 0$ & 11.7 & 11.9 & 11.7 & & NS & 0.45 \\
$18: 1 n-9$ & 35.8 & 31.4 & 32.8 & & NS & 1.45 \\
$18: 2 n-6$ & 22.9 & 22.0 & 19.8 & & NS & 1.21 \\
$18: 3 n-3$ & 3.0 & 9.0 & 7.7 & $*$ & 1.36 \\
\hline
\end{tabular}

${ }^{*} P<0.05$

†For details of composition of diets see Tables 1 and 2 . 
Table 9. Fatty acid profile ( $\mathrm{g} / 100 \mathrm{~g}$ total fatty acids) in outer backfat of pigs fed on a diet containing whole linseed

(Mean values for forty-eight pigs per group with their pooled standard error)

\begin{tabular}{|c|c|c|c|c|c|}
\hline \multirow[b]{2}{*}{ Fatty acid } & \multicolumn{3}{|c|}{ Diet† } & \multicolumn{2}{|c|}{ ANOVA } \\
\hline & LO & L50 & L100 & $P$ & Pooled SE \\
\hline $16: 0$ & 22.1 & $22 \cdot 2$ & $21 \cdot 2$ & NS & 0.87 \\
\hline $18: 0$ & 10.8 & 11.3 & 10.2 & NS & 0.90 \\
\hline $18: 1 n-9$ & $36 \cdot 2$ & 31.9 & $32 \cdot 6$ & $\star \star$ & 0.79 \\
\hline $18: 2 n-6$ & 22.6 & 21.5 & 21.3 & NS & 1.68 \\
\hline $18: 3 n-3$ & 2.8 & $10 \cdot 6$ & 8.8 & $* \star * *$ & 1.09 \\
\hline
\end{tabular}

** $P<0.01,{ }^{* * *} P<0.001$.

†For details of composition of diets see Tables 1 and 2.

outer backfat and 18:1 was reduced in the plasma and outer backfat. On the other hand, 18:0 remained unchanged in all tissues. The changes in fatty acid composition resulted in marked changes to the $n-6: n-3$ and $20: 4 n-6: 20: 5 n-3$ ratios. None of the longer-chain fatty acids (C20 or longer) were detected in the subcutaneous fat.

TBARS analysis showed no significant differences between diets. There was also no significant difference between the diets in the increase in TBARS from $1 \mathrm{~d}$ post mortem to $14 \mathrm{~d}$ post mortem. This suggests that the linseed had no negative effect on the oxidative stability of the meat (results not shown).

\section{Sensory panel results}

Least square means for the sensory traits are shown in Table 10. There was generally no difference in the eating quality of chops from pigs fed on the different diets and the differences found did not appear to be consistent across traits. Meat from pigs fed on diet L50 had lower levels of abnormal odour in the fat than meat from pigs fed on the other two diets but pigs fed on diet L100 had lower levels of skatole. In addition there was a significant interaction between diet and sex for boar flavour of the lean. Although overall there was no difference in boar flavour between the diets, male pigs fed on diet L100 had lower levels of boar flavour in the lean than male pigs fed on diet L50 (data not shown).

\section{Discussion}

This present study was designed to investigate the use of whole linseed to enhance the $n-3$ fatty acid content of pig tissues without adverse effects on carcass or meat quality. It has been a concern that feeding high levels of unsaturated fat in the diet of pigs may result in excessively soft fat in the carcass due to the fact that the fat deposited in the body of single-stomached animals reflects closely that of the diet. For example, Wood (1984) suggested that linoleic acid be restricted to a maximum of $16 \mathrm{~g} / \mathrm{kg}$ diet. Matthews \& Homer (1995) suggested that whole rapeseed meal should be limited in pig rations due to possible undesirable effects on fat softness and rancidity, although no eating quality effects were seen over the range of inclusion levels examined, and the Meat and Livestock Commission Blueprint for Quality British Pork restricts the total polyunsaturated fat content of the diet to $20 \mathrm{~g} / \mathrm{kg}$ diet (Meat and Livestock Commission, 1996). In this present study there was no effect of increasing the concentration of unsaturated fatty acids by increased inclusion of linseed in the diet on the firmness of the fat. Furthermore, it is clear from the results shown here that whole linseed can be fed to pigs under British conditions without incurring any effects on production or carcass quality variables.

The feeding of whole linseed at $100 \mathrm{~g} / \mathrm{kg}$ had no marked effect on eating quality as assessed by a trained sensory panel. This is in agreement with Cunnane et al. (1990). Romans et al. $(1995 a, b)$, however, received adverse comments from sensory panellists for bacon from pigs fed on 100 or $150 \mathrm{~g}$ whole linseed $/ \mathrm{kg}$ diet. It is likely that oxidation of the unsaturated fat was enhanced by curing, in this latter

Table 10. Least square means for sensory traits of meat from pigs fed on a diet containing whole linseed $\dagger$

(Mean values for forty-eight pigs per group with their pooled standard error)

\begin{tabular}{|c|c|c|c|c|c|}
\hline \multirow[b]{2}{*}{ Sensory trait§ } & \multicolumn{3}{|c|}{ Diet $\neq$} & \multicolumn{2}{|c|}{ ANOVA } \\
\hline & LO & L50 & L100 & $P$ & Pooled SE \\
\hline Juiciness & $14 \cdot 0$ & $14 \cdot 3$ & $14 \cdot 1$ & NS & 0.28 \\
\hline Tenderness & $17 \cdot 1$ & $16 \cdot 5$ & $16 \cdot 7$ & NS & 0.29 \\
\hline Pork flavour of lean & $14 \cdot 2$ & $14 \cdot 0$ & $13 \cdot 8$ & NS & 0.18 \\
\hline Abnormal flavour of lean & 2.36 & 2.07 & $2 \cdot 31$ & NS & 0.15 \\
\hline Boar flavour of lean & 2.09 & 2.06 & 1.78 & NS & 0.25 \\
\hline Pork flavour of fat & 11.5 & 11.6 & $11 \cdot 2$ & NS & 0.19 \\
\hline Abnormal flavour of fat & 1.8 & $2 \cdot 2$ & $2 \cdot 3$ & NS & 0.19 \\
\hline Boar flavour of fat & 1.6 & 1.6 & 1.5 & NS & 0.18 \\
\hline Overall acceptability & $15 \cdot 2$ & $14 \cdot 8$ & $14 \cdot 7$ & NS & 0.27 \\
\hline Pork odour of fat & $10 \cdot 3$ & $10 \cdot 1$ & 9.9 & NS & 0.16 \\
\hline Abnormal odour of fat & $3 \cdot 0$ & $2 \cdot 4$ & $3 \cdot 3$ & $* \star$ & 0.20 \\
\hline Androstenone odour & $1 \cdot 6$ & $1 \cdot 8$ & 1.5 & NS & 0.10 \\
\hline Skatole odour & $1 \cdot 6$ & $1 \cdot 6$ & $1 \cdot 3$ & * & 0.11 \\
\hline
\end{tabular}

${ }^{\star} P<0.05,{ }^{* *} P<0.01$.

†For details of sensory evaluation see p. 639

$\ddagger$ For details of composition of diets see Tables 1 and 2 .

$\S$ Sensory traits were scored on a 24 point pseudo line scale. 
case resulting in flavour problems. Ahn et al. (1996) also found no differences in sensory panel evaluation of the loin in meat vacuum-packaged after cooking. In meat stored 'loosely packaged', however, higher levels of $18: 3 n-3$ in the diet resulted in lower panel scores. Furthermore, analysis of TBARS indicated an increased development of rancidity with storage with increased $18: 3 n-3$ in the diet.

In the present experiment, the feeding of whole linseed had marked effects on the fatty acid composition of the tissues. Although it is not possible to explain the lack of difference between L50 and L100 in the $18: 3 n-3$ levels of the subcutaneous fat, both had levels at least double that observed in L0. It is particularly noteworthy that the longchain $n$-3 fatty acids, $20: 5 n-3$ and $22: 5 n-3$ were increased in the muscle and red offals (liver and kidney) in general agreement with several American studies. Cunnane et al. (1990) found that $50 \mathrm{~g}$ linseed $/ \mathrm{kg}$ diet had significant effects on $18: 3 n-3$ in meat and adipose tissue but elongated fatty acids were only increased in the organs (liver, heart, kidney and brain) rather than in muscle or adipose tissue. Romans et al. (1995a) fed linseed at $0,50,100$ or $150 \mathrm{~g} / \mathrm{kg}$ for $25 \mathrm{~d}$ before slaughter, resulting in increased $18: 3 n-3$ and $20: 5 n-3$ in the backfat. In a further trial, looking at the effect of length of time of feeding (Romans et al. 1995b), $150 \mathrm{~g}$ flaxseed $/ \mathrm{kg}$ fed for $0,7,14,21$ or $28 \mathrm{~d}$ resulted in an increase in $18: 3 n-3$ and $20: 5 n-3$ level in all tissues measured, up to $28 \mathrm{~d}$, but $22: 6 n-3$ was only increased in the inner/middle layer of backfat. Ahn et al. (1996) showed that increasing the level of $\alpha$-linolenic acid up to $35 \mathrm{~g} / \mathrm{kg}$ diet by inclusion of linseed resulted in increased $18: 3 n-3$, $20: 5 n-3$ and $22: 5 n-3$ in the loin muscle.

The Cardiovascular Review Group of the Committee on Medical Aspects of Food Policy (Department of Health, 1994) recommended a consumption of $78 \mathrm{~g}$ long-chain $n-3$ fatty acids per year $(1.5 \mathrm{~g} /$ week $)$ whilst the British Nutrition Foundation (1992) recommends a maximum ratio $18: 2 n-6: 18: 3 n-3$ of $6 \cdot 0$. It is possible to extrapolate from the results of this present study to estimate the impact that feeding linseed to pigs ( $100 \mathrm{~g} / \mathrm{kg}$ diet $)$ could have on the human diet. The baseline human diet was taken to be that described by Gregory et al. (1990) and this was used as the estimate of current intake of fatty acids.

In estimating the impact of a change in pig tissues on the human diet the following assumptions have been made: a national average 'carcass equivalent' consumption of pig meat of $22.2 \mathrm{~kg} / \mathrm{year}$ (Meat and Livestock Commission estimate; Meat and Livestock Commission (1999)); all the fat in the carcass is consumed (a reasonable assumption for pork where any fat trimmed during processing is used in product manufacture); the fatty acid composition of the backfat represents the fatty acid composition of all the fat depots in the carcass; that $800 \mathrm{~g}$ of the carcass fat tissue/kg is fatty acid; that $12 \mathrm{~g}$ of the lean tissue $/ \mathrm{kg}$ is fatty acid; that the L0 diet is representative of diets fed to pigs nationally. Based on these assumptions it was calculated that $2.5 \mathrm{~g} / \mathrm{year}$ of the current intake of long-chain $n-3$ fatty acids comes from pig meat. If this pig meat were replaced by meat from animals fed on $100 \mathrm{~g}$ linseed $/ \mathrm{kg}$, the same intake of pig meat would give $4.5 \mathrm{~g}$ long-chain $n-3$ fatty acids. This results in the prediction that $100 \mathrm{~g}$ linseed $/ \mathrm{kg}$ in the diet of pigs nationally would result in a reduction in the
$18: 2: 18: 3 n-3$ value from $7 \cdot 3$ to $5 \cdot 2$, bringing it within the British Nutrition Foundation (1992) recommendation, and would increase the contribution of pork to the recommended intake of long-chain $n$-3 PUFA from $3 \cdot 3$ to $5.8 \%$. These changes would represent a significant shift in the national diet improving the position of pork within the diet as a major contributor of essential $n-3$ fatty acids.

In conclusion, there is little evidence from this present study that increasing linseed in the diet of pigs from 0 to $10 \%$ will affect their carcass or meat quality. However, as expected, the fatty acid profiles of the tissues and fat showed increased concentrations of $\alpha$-linolenic acid, and hence decreased $n-6: n-3$ ratios, as the proportion of linseed in the diet increased. Furthermore, increased levels of $20: 5 n-3$, and in some cases $22: 5 n-3$, indicate that high dietary levels of $18: 3 n-3$ can increase the levels of beneficial long-chain $n$-3 PUFA in pig meat, having a potentially significant impact on the national diet.

\section{Acknowledgements}

This study was financially supported by a grant under the Ministry of Agriculture, Fisheries and Food Agro Food Quality LINK scheme (grant AFQ51). The authors are grateful for the practical technical support provided by staff of the Meat and Livestock Commission's Stotfold Pig Development Unit and Meat Technology Unit.

\section{References}

Ahn DA, Lutz S \& Sim JS (1996) Effects of dietary alpha-linolenic acid on the fatty acid composition, storage stability and sensory characteristics of pork loin. Meat Science 43, 291-299.

Bligh EG \& Dyer WJ (1959) A rapid method of total lipid extraction and purification. Canadian Journal of Biochemistry and Physiology 37, 911.

British Nutrition Foundation (1992) Unsaturated Fatty Acids Nutritional and Physiological Significance. London: Chapman and Hall.

British Standards Institute (1994) Assessors for Sensory Analysis. Part I. Guide to the Selection, Training and Monitoring of Assessors. Milton Keynes: British Standards Institute.

Cunnane SC, Stitt PA, Ganguli S \& Armstrong JK (1990) Raised omega-3 fatty acid levels in pigs fed flax. Canadian Journal of Animal Science 70, 251-254.

Department of Health (1994) Nutritional Aspects of Cardiovascular Disease. Report of the Cardiovascular Review Group, Committee on Medical Aspects of Food Policy. London: H.M. Stationery Office.

Dransfield E \& Kempster AJ (1988) Incidence of soft fat in British pigs. Animal Production 46, 502 Abstr.

Givens DI (1997) Sources of $n-3$ polyunsaturated fatty acids additional to fish oil for livestock diets. In New Meats: The Potential of Animal Diets to Change Meat Quality - A Review of $M A F F$ Research. London: Ministry of Agriculture, Fisheries and Food.

Gregory J, Foster K, Tyler H \& Wiseman M (1990) The Dietary and Nutritional Survey of British Adults. London: H.M. Stationery Office.

Irie M \& Sakimoto M (1992) Fat characteristics of pigs fed fish oil containing eicosapentaenoic acid and docosahexaenoic acid. Journal of Animal Science 70, 470-477.

Leskanich CO, Matthews KR, Warkup CC, Noble RC \& Hazzledine M (1997) The effect of dietary oil containing (n-3) 
fatty acids on the fatty acid, physiochemical, and organoleptic characteristics of pig meat and fat. Journal of Animal Science 75, 673-683.

Matthews KR \& Homer DB (1995) Whole rapeseed meal in pig finishing diets - effects on carcase and meat quality. Animal Science 60, 558 Abstr.

Meat and Livestock Commission (1996) Blueprint for Quality British Pork. Milton Keynes: Meat and Livestock Commission.

Meat and Livestock Commission (1999) Meat Demand Trends. Milton Keynes: Meat and Livestock Commission.

Placer ZA, Cushman LL \& Johnson BC (1966) Estimation of product of lipid peroxidation (malonyl dialdehyde) in biochemical systems. Analytical Biochemistry 16, 359-364.

Romans JR, Johnson RC, Wulfe DM, Libal GW \& Costello WJ (1995a) Effects of ground flaxseed in swine diets on pig performance and on physical and sensory characteristics and omega-3 fatty acid content of pork: I. Dietary level of flaxseed. Journal of Animal Science 73, 1982-1986.

Romans JR, Wulf DM, Johnson RC, Libal GW \& Costello WJ (1995b) Effects of ground flaxseed in swine diets on pig performance and on physical and sensory characteristics and sensory characteristics and omega-3 fatty acid content of pork: II. Duration of $15 \%$ dietary flaxseed. Journal of Animal Science 73, 1987-1999.

Vipond JE, Marie S \& Hunter EA (1995) Effects of clover and milk in the diet of grazed lambs on meat quality. Animal Science $\mathbf{6 0}$, 231.

Wood JD (1984) Fat deposition and the quality of fat tissue in meat animals. Fats in Animal Nutrition, p. 407 [J Wiseman, editor]. London: Butterworth. 